Part 1.

Studia Iuridica Lublinensia vol. XXVII, 1, 2018

DOI: $10.17951 /$ sil.2018.27.1.45

\author{
Tadeusz Biernat \\ Andrzej Frycz Modrzewski Kraków University, Poland \\ tadeuszbiernat@gmail.com
}

\title{
The Impact of the Judicial Precedents on the Normative Content of Human Rights ${ }^{1}$
}

\author{
Wpływ precedensu na treść normatywną praw człowieka
}

\author{
SUMMARY
}

The major objective of this article is to emphasise the importance and the role of precedent understood in broad terms - in forming the normative reality, exerting an impact on the content of normative elements, including human rights, particularly women's rights. Being an essential part of the normative reality, precedents are a particular kind of normative messages of a considerable power. Taken into account their narrative form, comprehensiveness of the content, media hype and possibilities of a mass broadcasting, precedents constitute an important element and play a significant role in forming the normative reality, which is characteristic for the present-day society. Being a phenomenon characteristic for a post-modernist society, the normative reality is understood in contrast to static conceptions of a normative or axionormative order, which have a given structure and distinct boundaries. The analysis of precedent rulings, stemming from various law orders, regarding women's equal rights in the employment process, aims at highlighting their importance both in forming the content of human rights and their impact on law and law enactment.

Keywords: precedent; normative approach; human rights; women's rights

The main aim of this article ${ }^{2}$ is to point out the role and the importance of widely understood precedents in shaping the normative space and its elements, among them human rights, and particularly women's rights ${ }^{3}$. I chose this problem due to

${ }_{1}$ This article was written as a part of the research project No. 2014/13/B/HS5/00565, financed by National Science Centre (NCN).

${ }^{2}$ From the various threads of my presentation entitled "The normative content of human rights in the law making and judicial precedents", during the IVR Conference, in the frame of the workshop "The potential of the precedent in the statutory legal order. The context of political and legal discourse", I chose the one that best reflects the "potential of precedents".

3 "Attaining equality between women and men and eliminating all forms of discrimination against women are fundamental human rights and United Nations values. Women around the world nevertheless 
two reasons. Firstly, because women's fundamental rights are one of the leading aspects of the human rights analysis. Judicial precedents and decisions of constitutional review in that field occupy a special position and are excellent examples of the dynamics of understanding and imparting substantial content to particular women's rights. Secondly, because shaping women's rights and fighting with their violations is still a live problem, having many dimensions, as evidenced by numerous examples of specific legal decisions (legislative and judicial), both in the "positive and negative" direction. It also reflects the dynamics of the post-modern normative space. It is beyond discussion that precedents play an important role in the creation of law and its application in the contemporary society. But by analysing the examples of judicial decisions in the area of women's rights protection, I want to point out the importance of indirect influence of precedents on shaping the normative space and creating different normative elements. This type of interaction highlights the role of the precedent in the contemporary societies. Taking up the problem, I would like to start with a brief comment about my research program in which the discussed problem is located. This will allow to the better understand my approach to the problem.

The discussed topic constitutes only one aspect of the planned research task, entitled "The normative sources of law in the post-modern society and law-making process". The scientific aim of the project is to investigate the relationships existing between law-making process and the elements of normative space characteristic to the contemporary, post-modern society.

The adopted scientific hypotheses are as follows: together with the social development there take place significant changes in the normative space, including law - as a basic element of the normative space. In the contemporary societies, the dynamics of the normative space causes both the emergence of new normative sources as well as a continuous clarification of their normative content. As a consequence, modern law is evolving in a strong reference to the external normative sources.

The detailed research hypothesis assumes that precedents, being an element of normative space, have also the force to change the normative space by defining the content of their elements, both at the level of values, principles and the formalized form: rules, norms. Precedents determine the trend - the direction of changes and their focus.

The purpose of the study is not only an attempt to validate the hypothesis but also has the implication on the creation of the research method in the form of

regularly suffer violations of their human rights throughout their lives, and realizing women's human rights has not always been a priority. Achieving equality between women and men requires a comprehensive understanding of the ways in which women experience discrimination and are denied equality so as to develop appropriate strategies to eliminate such discrimination". Women's Rights are Human Rights, United Nations Publication, HR/PUB/14/2, New York and Geneva 2014, p. 1. 
a referential model of law-making analysis - the study of law-making by referencing the rules to the normative sources. In other words, the referential model of law-making analysis allows providing the answer to the question of whether and to which normative sources the law refers to ${ }^{4}$. The proposed referential model of the analysis is a promising method for examining legal and non-legal normative complexity by a deep, descriptive focus on lived normativity, in all its forms. As I pointed out in the title of the paper, in the analysis of the empirical material I refer to the selected aspect of human rights - women's fundamental rights.

The development of the human rights, women's fundamental rights, is both the consequence and the illustration of the phenomenon of the dynamics and the complexity of the social system which is described in the following way:

It is beyond any dispute that we witness a process of growing complexity in the social sphere. We may disagree on some details of the social processes taking place nowadays, but the broad outline is uncontroversial - in principle, all societies are becoming more and more complex with the passage of time. When viewed from a historical and empirical perspective, a transition from simple societies, institutions, and interactions to complex, more sophisticated ones seems to be irreversible and inescapable 5 .

The complexity and the dynamics of the contemporary social relations create the phenomenon of forming in the post-modern society new normative elements influencing the complexity of the normative space.

The first issue which I would like to explain is the use of the term "normative space" and its application to the proposed analysis. In scientific studies, this term is sometimes used to define the space between the existing legal orders ${ }^{6}$. I apply this term in a different sense, its scope is similar to the concept of the socio-normative system, the axionormative system or normative order, but it differs considerably and, as I think, is more useful to the description and characteristics of the post-modern society. The vast majority of analyses in the theory and philosophy of law, and perhaps even all referring to the positioning of law in the normative order or in the axionormative system, contain the assumption of a strictly defined relationship between the elements of the system/normative order and their boundaries. The essence is defining elements and relations as the structure of the system, most often in the

${ }^{4}$ An example of such a reference might be the creation of "a constitutional pattern" in the process of rendering decisions by the Constitutional Court in respect of the constitutionality of the acts of law.

${ }_{5}^{5}$ T. Gizbert-Studnicki, M. Klinowski, Complexity of the Social Sphere and the Judicial Decision-Making Process, “Archivum Iuridicum Cracoviense" 2009, Vol. 42, p. 6.

${ }^{6}$ M. Zirk-Sadowski, Flexible Normative Space. Between the European Law and the Member State Law as a Source of Constitutional Identity, [in:] Towards Recognition of Minority Groups. Legal and Communication Strategies, eds. M. Zirk-Sadowski, B. Wojciechowski, K.M. Cern, Ashgate 2014, p. 237. 
form of hierarchical order and boundaries of the system, culturally, temporally and territorially designated.

The term "normative space" is more relevant to the characteristics of the range and the variability of the normative environment, the phenomenon which is beyond the mainstreams of scientific discussions. The social dynamics that I underlined before and the changes taking place cause that it is difficult to assign to the normative space a strictly and permanently defined structure and strictly defined boundaries. Key normative elements can play periodically most important role, but their normative functions are not always decisive. Together with the social development there take place significant changes in the normative space, including law - as a basic element of the normative space ${ }^{7}$. In broader terms, the notion of normative space includes more or less formalized normative elements (first of all systems of norms and standards - the law itself) that influence the creation of law both in the material and in the procedural dimension.

I would like to present two quotes that reflect well and justify the proposed approach:

We are normative animals, expressing evaluative judgments of appropriate claims and conduct. Normativity is thus universal. Legality isn't. Laws, as defined by centuries of Western convention, are points on a normative continuum and always rest within the wider matrix of less-institutionalized normativity. Legal norms are a subset of social norms. But if laws and norms may be distinguished in this way, they cannot be divorced. For this reason, jurists must take general normativity seriously and social scientists must respect legality's unique normative position ${ }^{8}$.

There has been no - and is now no - unified and pure legal or normative space, controlled respectively by either an all-embracing state or society. Instead, laws and norms always rest within the wider web of strong or deep legal pluralism, the totality of normative orders and more diffuse normative influences?.

Such an approach to the normative space requires a closer characterization in what sense I use the term "normative elements". It is not possible in this paper to present more broadly and defend the adopted concept of "normativity". I understand

7 "The increasing complexity of society and the ever more accentuated differentiation and enhancement of merely normative perspectives require the preparation of more suitable and efficient selective mechanisms, subtracted from the momentary distribution of power, in order to maintain the level of achieved development. In ways that can be totally different in particular, systems of specific interaction are produced, the so-called procedures, with the particular task to provide binding functions". P.L. Di Viggiano, Evolutionary Forms of Law and Social Systems, "Curentul Juridic. The Juridical Current. Le Courant Juridique" 2011, Vol. 45, p. 108.

${ }^{8}$ S.P. Donlan, To Hybridity and Beyond: Reflections on Legal and Normative Complexity, www. academia.edu/2078759/To_Hybridity_and_Beyond_Reflections_on_Legal_and_Normative_Complexity [access: 10.02.2018], p. 9.

${ }^{9}$ Ibidem, p. 12. 
the normative elements very broadly. Normative elements are aggregated forms of the normative statements which make claims about how someone should or ought to act, to behave in the social relationship. In this way, the normative space consist first of all of values (with respect to the norms implicit in those values); human rights; legal principles and norms; precedents, soft law norms; normative statements included in the justification of judicial decisions; normative statements included in the doctrine - to list the most important ones.

Pointing to the particular role of the precedents and the impact of the case-law on the development of the normative space, different definitions of precedents and their status in the legal systems should be considered. In the contemporary legal theory, there are two meanings of precedents. The former (de iure), refers to the formally binding rule of precedents, in the second meaning (precedents de facto) they stand for any influence of earlier judgments also of a potential character on later judgments ${ }^{10}$. The basic systemic difference is related to the role of the precedent in the common law system in which the precedent is binding law; it is a principle or rule established in a previous legal case that is either binding for a court when deciding subsequent cases with similar issues or facts. Apart from the basic form of the precedent, there are other meanings of this term, also in relation to common law rulings as persuasive precedent, not binding but useful or relevant and that may guide the judge in making the decision in a current case. In the jurisprudence, the broader meaning of precedents is indicated referring to the category of an earlier judicial decision, which can play a role in the statutory legal order. This is the basis for the wider classification of precedents. A more elaborate suggestion of a characteristics is presented by A. Peczenik who, besides a binding precedent, and a precedent having a legal power, introduces a category of precedents which constitutes an additional affirmation of the decision (further support) and a category of judgments "having value purely illustrative"11.

As it was stressed earlier, the characteristic feature of the normative space in the post-modern society is its dynamics; it stands both for the emergence of new normative sources as well as for a continuous clarification of their normative content. Precedents, by their very nature, have effects on all of the above-mentioned dimensions. Furthermore, the force of the effects is a derivative from the privileged position of precedents. I would like to point only at the three aspects. Firstly, the special position of precedents is related to the narrative formula of precedents and their mediality. In the content of the ruling and the justification of precedents, there manifests itself a history, connected with a particular event, most interesting to the media, as in the following example. Israeli woman wins a discrimination case over

10 T. Zych, W poszukiwaniu pewności prawa, Torun 2017, p. 30.

11 A. Peczenik, The binding force of precedents, [in:] Interpreting Precedents: A Comparative Study, eds. D.N. MacCormick, R.S. Summers, Dartmouth, 1997, p. 463. 
airline seat. An 81-year-old lawyer and refugee from the Nazis is suing El Al Israel Airlines for discrimination after she was moved from her seat to make way for an ultra-orthodox man on a flight from the U.S. to Israel. The court in Jerusalem issued a landmark decision on June $21^{\text {st }}$, ruling that women aboard airplanes cannot be asked by airline staff to change seats so that ultra-orthodox Jewish men can avoid sitting next to them. The ruling came in a lawsuit brought by Renee Rabinowitz, who, aboard a flight from Newark, New Jersey, to Tel Aviv in 2015, was asked by El Al flight staff to change seats so an ultra-orthodox man wouldn't have to sit next to her. Some strictly religious Jewish men, as a matter of policy, refuse to sit next to women they don't know out of a fear that even incidental contact between himself and a strange woman would be indecent ${ }^{12}$. This case had a great reaction, not only in the media. Welcoming the judgment, the Israel Religious Action Center, which is linked to the liberal Movement for Reform Judaism, said that the court's decision set a precedent. "With the implementation of this ruling, a passenger asking to move their seat because of their gender will qualify as discrimination, and as such will be prohibited", it said in an English-language statement ${ }^{13}$. Secondly, the rule expressed in the precedent by its relationship to specific facts is more understandable and clear than the abstract general norm. Thirdly, in the modern world the emergence of new forms of mass communication, gives the unlimited possibilities of disseminating the content of the precedents ${ }^{14}$. This content is not only easily accessible but also easy to find by the possibility of identifying specific, similar situations.

Treating precedents in the broad sense and bearing in mind the above-mentioned particular features, there emerge three most significant areas in which the precedent influences the development of the normative space.

The first area is related to the influence of precedents on law-making. In this case, the relationships are very complex and can be considered on many levels. In general, indirect and direct influence can be discussed. The indirect impact would require very extensive analyses that go beyond the scope of this study because it is the problem of law-making in a particular legal environment with all its elements.

12 J. Sharon, Israeli Court: Haredi Calls for Women to Move Seats on El Al Now Illegal, "The Jerusalem Post", www.jpost.com/Israel-News/Court-Illegal-to-ask-women-to-move-seats-on-flightsdue-to-haredi-demands-497608 [access: 10.02.2018].

${ }_{13} \mathrm{P}$. Beaumont, Israeli airline can't make women move seats for religious reasons, court rules, "The Guardian", www.theguardian.com/world/2017/jun/22/israeli-airline-cant-make-women-moveseats-for-religious-reasons-court-rules [access: 10.02.2018].

${ }^{14}$ In some cases, the need to disseminate court judgments is emphasized officially. "It highlights the need for the dissemination of relevant decisions of the Court of Justice of the European Union (CJEU) and for an exchange of national court decisions in line with CJEU and European Court of Human Rights case-law pertaining to the provisions of the Employment Equality Directive". Report on application of Council Directive 2000/78/EC of 27 November 2000 establishing a general framework for equal treatment in employment and occupation ('Employment Equality Directive') (2015/2116 (INI)) A8-0225/2016, point 92. 
Direct impact is often indicated in literature, and this reflects the "precedent potential”"15.

Another area is related to the influence of precedents on different actions which play important role in forming normative reality, social norms, and soft law norms, as well as social movements oriented at the change of law. One of the forms of the discussed phenomenon is described as "impact litigation" in the following way:

The aim of "impact litigation" is to strategically choose cases to bring to the highest courts in order to maximize the chances of changing the legal precedent in an area of law important to the affected group and its supporters. It has a catalytic effect on mobilizing reform movements to press governments into comprehensive legislative reform. Impact litigation that successfully challenges discriminatory laws based on unconstitutionality in one country can influence the interpretation and application of constitutional provisions by courts in other countries. For this potential to be realized, it is important that the case addresses the key legal issue in question ${ }^{16}$.

In general, due to the relationships we have, we can talk about diffusion between elements of the normative space.

The main area is related to the impact of precedents on the content of particular human rights, but in fact, it is a creation of the content of these rights. I would like to present this problem by analysing the issues of women's equal right to employment, which expresses broader human rights on equality. The problem is not new, and for many years there has been pointed out the need for its solution.

There is no logical justification for sex segregation in employment. The earmarking by employers, unions and employment agencies of all well-paid, interesting jobs as "male" jobs and most poorly-paid, tedious jobs as "female" jobs is a cruel means of keeping women in a condition of poverty and degradation ${ }^{17}$.

Strong pressure on changes in this area does not mean that the problem has been resolved, although many changes have taken place in international and national law.

Generally, women's equal right to employment is a constitutionally entrenched fundamental right and is repeatedly affirmed in a series of laws in many countries. But the issue that arises is whether this equality is merely formal or substantial. It is of a key importance to the discussed issue that the legislation introduced,

15 The case Vishaka \& Ors. v. State of Rajasthan \& Ors (1997) 6 SCC 241. This verdict was superseded by the Sexual Harassment of Women at Workplace (Prevention, Prohibition and Redressal) Act, 2013. See: A. Mandhani, Women's Day Special: 15 Supreme Court judgments that made India a better place for women, www.livelaw.in/womens-day-special-15-judgments-that-made-india-abetter-place-for-women [access: 11.02.2018].

${ }_{16}$ M. Hallward-Driemeier, T. Hasan, Empowering Women: Legal Rights and Economic Opportunities in Africa, World Bank Publications, 2012, DOI: https://doi.org/10.1596/978-0-8213-9533-2, p. 96.

${ }_{17}$ C.G. Berger, Equal Pay, Equal Employment Opportunity and Equal Enforcement of the Law for Women, "Valparaiso University Law Review" 1971, Vol. 5, p. 328. 
although significantly changing the scope of women's rights, cannot provide for actual women's equality. Legal acts are only "a general framework for combating discrimination on various grounds" 18 . In this regard, the question is how to ensure that these rights are exercised and what is the role of the judiciary in this respect. The following quote illustrates this problem:

Before advancing with this discussion, it is, however, important to acknowledge that despite progressive attempts by the judiciary discrimination against women in employment still persists worldwide. Nevertheless, it is evident that awareness of discrimination and the need for legal sanctions to dismantle discrimination has been raised higher than ever before and judicial activism does have a significant contribution to achieve this end. This activist task has not only been limited to implementing the stated and inherent objectives of laws to eliminate discrimination in employment, but also extends to remedy the dynamics of discrimination. Pursuant thereto, the judiciary has provided very authoritative and expansive application of the substantive equality to the detection and remedy of discriminatory practices in the workplace ${ }^{19}$.

Assuming that the judiciary plays an important role in determining the equality of women's rights in the workplace, two points should be noted. In that case, the issue is very complicated due to the interdependence. The basis for issuing judgments is formal equality expressed as one of the fundamental human rights. At the same time, the judgment goes beyond such an understanding of equality, giving it a specific meaning. There are additional difficulties in issuing such a decision, which is based on the overcoming of additional constraints, including stereotypes and bias $^{20}$. However, there is no doubt that in the case law, and particular in precedents, a particular content of women's rights is provided.

Formal equality proved ineffective in dealing with women's practical needs and perspectives and law's continued tolerance of some traditional perceptions about women's roles reinforces their subordination in employment. A substantive approach seeks to improve women's position in employ-

18 "Whereas the Court of Justice of the European Union (CJEU) stressed, in Römer, that the Employment Equality Directive does not itself lay down the principle of equal treatment in the field of employment and occupation, but provides a general framework for combating discrimination on various grounds". Report on application of Council Directive 2000/78/EC of 27 November 2000, point 92. Case C-147/08, Römer [2011] ECR I-3591.

19 A. Begum, Implementing Women's Equal Right to Employment in Bangladesh: A Comparative Judicial Approach With Special Reference to India, Canada and Australia, "Canberra Law Review" 2012, Vol. 11(1), p. 14.

${ }^{20}$ See: Stereotyping by the judiciary Vertido v. Philippines (Committee on the Elimination of Discrimination against Women, Communication No. 18/2008, Views adopted on 16 July 2010): "The Committee considered gender stereotypes in a case of rape, emphasizing "that stereotyping affects women's right to a fair and just trial and that the judiciary must take caution not to create inflexible standards of what women or girls should be or what they should have done when confronted with a situation of rape based merely on preconceived notions of what defines a rape victim or a victim of gender-based violence, in general«". Women's Rights..., p. 111. 
ment by eliminating all forms of discrimination in employment. The precedents across many nations illustrate how legislative and judicial efforts have made a significant departure from the traditional concept of 'equality' and developed a substantive approach to accommodate women's particular experiences in the workplace ${ }^{21}$.

Examples of adopting such an approach to equal employment rights for women are clearly seen in numerous judicial decisions, and the judgments and their justifications contain specific normative content.

Without a comprehensive analysis of precedents, it is difficult to fully characterise the normative content. In the justification of the discussed problem, I would like to point out only to one of the most characteristic examples referring to the question of women's employment rights in the context of their inherent physical characteristics.

The Supreme Court of the United States decided in International Union, UAW v. Johnson Controls and addressed the issue of fetal hazards. In this case, the employer barred women of childbearing age from certain jobs due to the potential harm that could occur to a fetus. The Court ruled that the employer's restriction against fertile women performing "dangerous jobs" constitutes sex discrimination under Title VII. The Court further ruled that the employer's fetal protection policy could be justified only if being able to bear children was a bona fide occupational qualification (BFOQ) for the job. The fact that the job posed risk to fertile women does not justify barring all fertile women from the position ${ }^{22}$.

Parveen v. Bangladesh Biman was the case on employment rights of women before the Supreme Court (SC) of Bangladesh. The case concerned the constitutional legality of the Biman Corporation Employees (Service) Regulation 1979 that reduced the age of retirement of women from the Corporation. In 1995, a new Regulation 11 was promulgated, which reduced the age of retirement of the flight stewardess to 35 from 57 but for stewards the retirement age was fixed at 45 years. The Corporation contended that the business of the Biman (Airbus) is competitive and 'the stewardesses are appointed to obtain maximum service for the Biman' which has to be obtained from young and smart stewardesses. Drawing upon these issues, the SC chose to adhere to the 'similarly situated test' by placing exclusive emphasis on 'fixing an equal age' for Parveen and her male colleagues of similar ranks in the Corporation for retirement ${ }^{23}$.

A leading case on women's employment in India was Nargeesh, in which the Court declared a service regulation of Air India that made pregnancy a bar to the continuance in service as an airhostess unconstitutional. The Court held that such

${ }^{21}$ A. Begum, op. cit., p. 2.

${ }^{22}$ Selected Supreme Court Decisions, www.eeoc.gov/eeoc/history/35th/thelaw/supreme_court. html [access: 11.02.2018].

${ }^{23}$ A. Begum, op. cit., p. 9. 
a bar is tantamount to obstructing the ordinary course of human nature and was 'not only a callous and cruel act but an open insult to Indian womanhood, the most sacrosanct and cherished institution'24.

In Australian Postal Commission (APC), the Court of Appeal, for example, examined the adverse impact of APC's neutral policies on two women where they were denied permanent appointments due to their lack of medical fitness - a specified bodyweight measured by height and sex being specified in APC's policy. The Court favoured them by observing that the requirements may fairly measure the skills of all candidates but operate to disqualify women because of their inherent physical characteristics ${ }^{25}$.

The above judicial findings are the consequence of new ideas of understanding women's employment rights and give them new content.

The presented comments in the very preliminary form define the essence of the phenomenon, which is by the very nature extensive. The issues discussed in this article touch only upon the problem of the role of precedents and their importance both in shaping the content of the human rights and the elements of the normative space.

\section{REFERENCES}

Beaumont P., Israeli airline can't make women move seats for religious reasons, court rules, "The Guardian", www.theguardian.com/world/2017/jun/22/israeli-airline-cant-make-women-moveseats-for-religious-reasons-court-rules [access: 10.02.2018].

Begum A., Implementing Women's Equal Right to Employment in Bangladesh: A Comparative Judicial Approach With Special Reference to India, Canada and Australia, "Canberra Law Review" 2012, Vol. 11(1).

Berger C.G., Equal Pay, Equal Employment Opportunity and Equal Enforcement of the Law for Women, "Valparaiso University Law Review" 1971, Vol. 5.

Di Viggiano P.L., Evolutionary Forms of Law and Social Systems, "Curentul Juridic. The Juridical Current. Le Courant Juridique" 2011, Vol. 45.

Donlan S.P., To Hybridity and Beyond: Reflections on Legal and Normative Complexity, www.academia.edu/2078759/To_Hybridity_and_Beyond_Reflections_on_Legal_and_Normative_Complexity [access: 10.02.2018].

Gizbert-Studnicki T., Klinowski M., Complexity of the Social Sphere and the Judicial Decision-Making Process, "Archivum Iuridicum Cracoviense" 2009, Vol. 42.

Hallward-Driemeier M., Hasan T., Empowering Women: Legal Rights and Economic Opportunities in Africa, World Bank Publications, 2012, DOI: https://doi.org/10.1596/978-0-8213-9533-2.

Mandhani A., Women's Day Special: 15 Supreme Court judgments that made India a better place for women, www.livelaw.in/womens-day-special-15-judgments-that-made-india-a-better-place -for-women [access: 11.02.2018].

Peczenik A., The binding force of precedents, [in:] Interpreting Precedents: A Comparative Study, eds. D.N. MacCormick, R.S. Summers, Dartmouth, 1997.

\footnotetext{
${ }^{24}$ Ibidem, p. 15.

${ }^{25}$ Ibidem, p. 19.
} 
Pobrane z czasopisma Studia Iuridica Lublinensia http://studiaiuridica.umes.pl Data: 26/04/2023 10:31:30

The Impact of the Judicial Precedents on the Normative Content of Human Rights

Report on application of Council Directive 2000/78/EC of 27 November 2000 establishing a general framework for equal treatment in employment and occupation ('Employment Equality Directive') (2015/2116 (INI)) A8-0225/2016, point 92.

Selected Supreme Court Decisions, www.eeoc.gov/eeoc/history/35th/thelaw/supreme_court.html [access: 11.02.2018].

Sharon J., Israeli Court: Haredi Calls for Women to Move Seats on El Al Now Illegal, "The Jerusalem Post", www.jpost.com/Israel-News/Court-Illegal-to-ask-women-to-move-seats-on-flights-dueto-haredi-demands-497608 [access: 10.02.2018].

Women's Rights are Human Rights, United Nations Publication, HR/PUB/14/2, New York and Geneva 2014.

Zirk-Sadowski M., Flexible Normative Space. Between the European Law and the Member State Law as a Source of Constitutional Identity, [in:] Towards Recognition of Minority Groups. Legal and Communication Strategies, eds. M. Zirk-Sadowski, B. Wojciechowski, K.M. Cern, Ashgate 2014. Zych T., W poszukiwaniu pewności prawa, Torun 2017.

\section{STRESZCZENIE}

Głównym tematem artykułu jest wskazanie na znaczenie i rolę szeroko rozumianego precedensu w kształtowaniu przestrzeni normatywnej, oddziaływanie na treści normatywnych elementów, w tym praw człowieka, a w szczególności na prawa kobiet. Precedensy, będąc istotną częścią składową przestrzeni normatywnej, są szczególnego rodzaju komunikatami normatywnymi, o znacznej sile oddziaływania. Ze swej istoty, a zwłaszcza ze względu na narracyjną formułę, zrozumiałość treści, medialność i możliwości szerokiego upowszechnienia, stanowią ważny element i odgrywają istotną rolę w kształtowaniu przestrzeni normatywnej, charakterystycznej dla współczesnego społeczeństwa. Pojęcie przestrzeni normatywnej, zjawiska charakterystycznego dla społeczeństwa postmodernistycznego, jest rozumiane w opozycji do statycznych koncepcji ładu normatywnego lub aksjonormatywnego, o określonej strukturze i wyraźnie zaznaczonych granicach. Analiza precedensowych orzeczeń, pochodzących z różnych porządków prawnych, a odnoszących się do równouprawnienia kobiet w zatrudnieniu, ma ukazać ich wagę zarówno w formułowaniu treści praw człowieka, jak i oddziaływaniu na prawo i jego tworzenie.

Słowa kluczowe: precedens; przestrzeń normatywna; prawa człowieka; prawa kobiet 